\title{
Effect of Dehulling on Proximate Composition and Functional Properties of Lima Bean (Phaseolus lunatus) Grown in Enugu State
}

\author{
Juliana C. Ibeabuchi ${ }^{1}$, Damaris C. Okafor ${ }^{1}$, Ndidiamaka N. Ahaotu ${ }^{1}$, Chioma N. Eluchie ${ }^{1}$, Ijeoma M. Agunwah ${ }^{1}$, \\ Michael N. Chukwu ${ }^{2} \&$ Chinyere Amandikwa ${ }^{1}$ \\ ${ }^{1}$ School of Engineering and Engineering Technology, Department of Food Science and Technology, Federal \\ University of Technology, Owerri, Imo State, Nigeria \\ ${ }^{2}$ Department of Food Technology, Abia State Polytechnic, Aba, Abia State, Nigeria \\ Correspondence: Damaris C. Okafor, School of Engineering and Engineering Technology, Department of Food \\ Science and Technology, Federal University of Technology, P.M.B. 1526, Owerri, Imo State, Nigeria. Tel: \\ 234-803-783-7771. E-mail: okafordamaris@gmail.com or damaris@ualberta.ca
}

Received: November 4, 2018

Accepted: November 23, 2018 Online Published: March 16, 2019

doi:10.5539/jfr.v8n2p116

URL: https://doi.org/10.5539/jfr.v8n2p116

\begin{abstract}
This physical properties, proximate composition and functional properties of Lima bean (Phaseolus lunatus) obtained from Enugu State were studied. The result obtained for dehulled and undehulled lima bean with respect to proximate composition gave the following value for dehulled lima bean: moisture $7.18 \%$, crude fat $4.67 \%$, protein $14.24 \%$, crude fiber $17.89 \%$, ash $0.66 \%$ and carbohydrate $55.36 \%$ while undehulled lima bean contents were moisture $4.30 \%$, crude fat $2.62 \%$, protein $16.31 \%$, crude fiber $18.00 \%$, ash content $2.13 \%$, carbohydrate $56.14 \%$. Moisture, crude fat, protein and ash contents were significantly different than crude fiber and carbohydrate. The functional properties showed higher values for dehulled than undehulled okpokoro flour. The emulsion capacity $4.35(\mathrm{ml} / \mathrm{g})$ for dehulled and $3.03(\mathrm{ml} / \mathrm{g})$ for undehulled; foam capacity $31.67 \%$ for dehulled and $25.33 \%$ for undehulled; bulk density $0.82(\mathrm{ml} / \mathrm{g})$ and $0.88(\mathrm{ml} / \mathrm{g})$ water absorption capacity $2.238(\mathrm{ml} / \mathrm{g})$ for dehulled and $1.98(\mathrm{ml} / \mathrm{g}$ ) for undehulled etc., showing that the dehulled okpokoro flour had better functional potentials than the undehulled flour.
\end{abstract}

Keywords: lima bean, dehulled, undehulled, proximate, functional

\section{Introduction}

Lima bean (Phaseolus lunatus) also known as "okpokoro" is among the local leguminous crops cultivated in Enugu-state, Eastern part of Nigeria. This crop is cultivated because of its high fiber content and protein content. It is an important food legume crop grown in the semi-arid tropics covering Asia, Africa, Southern Europe, Central and South America (Muhammad, Jacobson \& Eggunm, 1979). Leguminous crops are rich in protein, fiber, energy and other nutrient in the diet of large populace in this region and around the world. They are also an excellent source of thiamine thereby contributing to other water-soluble vitamins like (riboflavin, niacin, pydoxine and folate) and minerals (phosphorus, iron, calcium and magnesium) (Ramicharran \& Walker, 1985). They are second to cereal as a source of animal and human food and have high food value. According to Doughty and Walker (1982), such leguminous crop serves as supplementary protein to cereal based diets rice and some starchy food. A mature legume seed is made up of seed coat (testa or hull) the cotyledons and the embryo (Okaka, 1997). In some parts of Africa, the green pod of legume crops such as string bean, wringed bean and lima bean and some other cowpea varieties are used as vegetables. They are mostly legumes cultivated in Nigeria together with locust soya bean, cowpea, lima bean, bambara groundnut, African yam bean e.t.c.

Lima bean (Phasecous lumatus) is also called "butter bean". It has a delicate flavour that compliment a wide variety of dishes. The pods of lima bean are flat, oblong and slightly curved, average about three inches in length. The high fiber content of lima bean helps to reduce spikes in blood sugar after meals. Their seeds are generally brown in colour, although certain varieties have colours such as white, red purple and black. The planting season is between April and June and harvesting starts about 5 months after planting and storage is by silos or by tying on ropes kept on kitchen where smoke will dry it. Therefore, the aim of this work was to determine the functional properties and proximate composition of flours obtained from the dehulled and undehulled lima bean so as to find its useful applications in food system. 


\section{Material and Methods}

\subsection{Procurement of Material}

The cultivar of Lima bean (Phaseolus lunatus) was obtained from Emene in Enugu State, Nigeria. The chemicals (analytical grade) and equipment used for this research were from the Food Science and Technology Laboratory, Federal University of Technology, Owerri.

\subsection{Sample Preparation}

The Lima bean seeds were manually cleaned and sorted to removed dirt, extraneous materials as well as unwholesome seeds. To obtain the dehulled sample, certain quantities of the seeds were soaked in water for 55 minutes to facilitate removal of the seed coat from the cotyledon. After dehulling, the seeds were sun-dried and ground to obtain fine flour; the flour was sieved through muslin cloth. The undehulled was also ground but in this case, this was done without separation of the seed coats from the cotyledon. The flour samples were then stored in a clean, dry and air tight container for experimental analysis.

\subsection{Physical Properties}

\subsubsection{Seed Characteristics}

Raw seed were randomly selected from the butch and then examined by subjective assessment for shape, testa texture seed colour, testa attachment to the cotyledon. This was done following the procedure of Fashakin and Fasanya (1988). The attachment of the seed coat to the cotyledon was described as being firm or loosed depending on its resistance to separation after soaking. The texture was also described with regards to how winkled and smooth the seeds appeared to the eye. Other parameters were also described accordingly.

\subsubsection{Seed Weight}

Weight of 100 seeds randomly selected was determined by weighing (AOAC, 2005). The average seed weight was than calculated.

\subsubsection{Seed Size}

The size of seed was dimensionally characterized by measuring ten randomly selected seeds for their length, width and thickness in $\mathrm{mm}$ using a vernier caliper of about $0.01 \mathrm{~mm}$ precision. The average seed size was then calculated.

\subsection{Proximate Composition of Lima Bean Flour Samples}

The procedures for the chemical analysis, for moisture, Ash, Crude protein, crude fibre fat and carbohydrate were outlined by the Association of Official Analytical Chemists (AOAC, 2005). The analyses were carried out on both the dehulled and undehulled lima bean seeds flour and the result were obtained in triplicates.

\subsection{Functional Properties of the Lima Bean Flour Sample}

\subsubsection{Determination of Water Absorption Capacity}

The method of Sosulski (1962) which was described by Abbey and Ibeh (1988) was adopted in this determination. One gram $(1 \mathrm{~g})$ of each sample was weighed out into a dry, clean centrifugal tube and both weights noted. $10 \mathrm{ml}$ of distilled water was poured into the tube and properly mixed with the sample to make a suspension. It was then centrifuged at speed of $3500 \mathrm{rpm}$ for $15 \mathrm{~mm}$. After which supernatant was discarded then the tube and its content re-weighed and noted. The gain in weight is the water absorption capacity of the test sample (Ibeabuchi, 2014).

$$
\% \mathrm{WAC}=\frac{\text { weight gain }}{\text { weight of sample }} \times 100
$$

\subsubsection{Determination of Oil Absorption Capacity}

The method of Sosulski (1962) which was described by Abbey and Ibeh (1988) was adopted in this determination. One gram of each sample was weighed into a dry, clean centrifugal tube and both weights noted. $10 \mathrm{ml}$ of refined vegetable oil was poured into the tube and properly mixed with the flour. The suspension was centrifuged at $3500 \mathrm{rpm}$ speed for $15 \mathrm{~min}$, then the supernatant was discarded, the tube with its content re-weighed. The gain in mass is the oil absorption capacity of the sample.

$$
\mathrm{OAC}=\frac{\text { weight gain }}{\text { weight of sample }} \times 100
$$




\subsubsection{Determination of Foam Capacity and Stability}

This was determined using the method of Onwuka (2005). One gram of the ogiri was whipped into $100 \mathrm{ml}$ distilled water and its volume noted. The suspension was blended with a warming blender 1600rpm for $5 \mathrm{~min}$. It was then poured into a $250 \mathrm{ml}$ measuring cylinder, its volume noted and recorded. Foam capacity is expressed as percentage increase in volume in the formula below:

$$
\text { Foam capacity }=\frac{\text { Volume after } \text { whipping }- \text { volume before whipping }}{\text { Volume before whipping }}
$$

The volume of foam capacity and the volume of the foam after 60 minutes were used to determine the stability for the whipping as expressed in equation 10 .

$$
\text { Foam Stability }=\frac{\text { foam volume after } 60 \text { minutes }}{\text { initial foam volume }} \times 100
$$

\subsubsection{Determination of Emulsion Capacity}

This was done using the method of Beuchat, Chery and Quim (2000). The sample (2g) and $25 \mathrm{ml}$ of distilled water were blended for 30 seconds using a magnetic stirrer. After complete dispersion, $25 \mathrm{ml}$ refined vegetable oil was added continuously through a burette and continued the blending for another 30 seconds. The mixture was transferred into a centrifuge tube and was centrifuge at $1600 \mathrm{rpm}$ for 5 minutes. The volume of oil separated from the sample after centrifugation was read directly from the tube and was recorded. The emulsion capacity was expressed as $\mathrm{ml}$ of oil emulsified per gram of sample.

$$
\text { Emulsion Capacity }=\frac{\text { Height of emulsified layer }}{\text { Height of } \text { whole solution in the centrifuge tube }} \times 100
$$

\subsubsection{Determination of Swelling Index}

About $3 \mathrm{~g}$ of ogiri sample was put into a clean, dry, graduated $50 \mathrm{ml}$ cylinder. The sample was gently levelled in the cylinder and the volume noted. $30 \mathrm{ml}$ of distilled water was added to each sample. The swirled cylinder was allowed to stand for $60 \mathrm{~min}$, while the change in volume was recorded every $15 \mathrm{~min}$ (Njoku \& Banigo, 2006).

$$
\text { Swelling Index }=\frac{\text { volume occupied by sample after swelling }}{\text { volume occupied by sample before swelling }}
$$

\subsubsection{Bulk Density}

Using the procedure of Onwuka (2005), about $5 \mathrm{~g}$ ogiri was put into a $10 \mathrm{ml}$ measuring cylinder gently. The bottom of the cylinder was tapped gently on the laboratory bench severally until there was no further change of the sample level to a constant volume. The bulk density was calculated using the formula below.

$$
\text { Bulk Density }=\frac{\text { Mass of Ogiri sample }}{\text { Volume of ogiri }}
$$

\subsection{Statistical Analysis}

Data obtained from this experiment was subjected to T-test using Microsoft Excel 2013.

\section{Result and Discussion}

\subsection{Physical Properties of Lima Bean Seed}

The result of the physical properties of the lima bean seed is presented in the Table 1 . From the Table 1, the average seed weight was $0.14 \mathrm{~g}$. The colour of the cultivar was dark brown with an eye that was brown in colour. The testa was smooth though firmly attached to the cotyledon. The dimensions of the lima bean seed on average 8.3, 5.1 and 3.2 for length, width and thickness respectively. These results compared favorably with the report of Maia, Ohveriram, Natos, Moreira and Vasconcelas (2000) that reported the length range of 6.7 to $11.1 \mathrm{~min}$ and width of 5.2 to 8.1 for lima bean cultivar.

Table 1. Physical Properties of Lima Bean Seed

\begin{tabular}{llllll}
\hline $\begin{array}{l}\text { Average seed } \\
\text { weight }(\mathbf{g})\end{array}$ & $\begin{array}{l}\text { Seed } \\
\text { colour }\end{array}$ & $\begin{array}{l}\text { Eye } \\
\text { Characteristic }\end{array}$ & $\begin{array}{l}\text { Testa } \\
\text { Attached to }\end{array}$ & $\begin{array}{l}\text { Testa } \\
\text { Size }\end{array}$ & $\begin{array}{l}\text { Seed } \\
\text { Cotyledon }\end{array}$ \\
\hline $0.14 \pm 0.02$ & Dark brown & Freshly smooth & Firm harvested & $8.3 \times 5.1 \times 3.2$ & \\
\hline
\end{tabular}




\subsection{Proximate Composition of Lima Bean Seed}

The proximate composition for the dehulled seed flour and undehulled was conducted in triplicates and the result shown in Table 2. The moisture content of the dehulled was found to be $7.18 \%$ while that of the undehulled was $4.30 \%$. The moisture content of the dehulled lima bean seeds was significantly high ( $p>0.05)$ and this could be as a result of the prolonged soaking period of the seeds before dehulling. The moisture content level of the flour is desirable because at level of $15 \%$ there is a high possibility of bacterial action and mould growth, thus making the flour to have a short shelf life probably due to microbial infestation on the flour and/or development of hydrolytic rancidity (Ihekoronye \& Ngoddy, 1985).

Table 2. Mean Values for Proximate Composition of Dehulled and Undehulled Lima Bean Flour

\begin{tabular}{lll}
\hline Components (Dry weight basis) & Dehulled seeds (\%) & Undehulled seeds (\%) \\
\hline Moisture & $7.18^{*} \pm 0.628$ & $4.30 \pm 0.412$ \\
Protein & $14.24 \pm 1.372$ & $16.81^{*} \pm 0.673$ \\
Crude Fat & $4.67^{*} \pm 0.707$ & $2.62 \pm 0.233$ \\
Crude fiber & $17.89 \pm 0.758$ & $18.00^{*} \pm 0.758$ \\
Ash & $0.66 \pm 0.153$ & $2.13^{*} \pm 0.221$ \\
Carbohydrate & $55.36 \pm 1.347$ & $56.14^{*} \pm 1.685$ \\
\hline
\end{tabular}

*means with asterisk $(*)$ within a row is significantly different $(\mathrm{P}>0.05)$

The moisture content of the dehulled and undehulled lima bean is $7.18 \%$ and $4.30 \%$ respectively. The value recorded agreed with that of Onwuliri and Obu (2002) of 5-10\%. These values were suitable since lima bean undergoes long soaking period prior to dehulling. The fat content varied significantly with the values of $4.67 \%$ and $2.62 \%$ for both dehulled and undehulled lima bean respectively. This is in agreement with the report of Davidson et al., (1975); they stated that lima bean is one of the specie in the leguminous crops that contains 1-5\% fats. This values also fit into established values as reported by Edeogu, Ezeonu, Okaka, Ekuma and Elon (2007); where they stated the range of $1.85-2.45 \%$ on dry matter basis. The values thus obtained were acceptable because lima bean had low fat content. The flour from lima bean had good fibre content, though the dehulled flour had no significant different from the undehulled, with a fibre content of $17.89 \%$ and $18.00 \%$ both dehulled and undehulled lima bean. This could be attributed to the soaking and dehulling operations. This analysis shows that lima beans contain much fibre than any other leguminous crops. Fiber is a very important component of food. It has been reported to have a major influence on metabolism in gastrointestinal track. Legumes contain high fibers which slow down the release of glucose in to the blood stream, hence high legume diet are recommended for diabetic patient (Jenkins, Woleverm \& Taylor, 1982). The protein contents of lima bean were $14.24 \%$ and $16.81 \%$ for both dehulled and undehulled lima bean. While the ash content ranges from $0.66 \%$ and $2.13 \%$ for both dehulled and undehulled lima bean. The values obtained for undehulled lima bean can be attributed to the non-soaking process in the method used to convert the mineral that might have leached away into the soaked water in the case of the dehulled sample. The carbohydrate values range from $55.36 \%$ to $56.14 \%$ for both dehulled and undehulled lima bean and these agree reported by Onwuliri and Obu (2002) of (55.3-65.8\%), the difference in the carbohydrate values could as a result of dehulling which involved the removal of the hulls. These lead to the low values obtained for the dehulled sample. Nevertheless, carbohydrate generally functions as storage form of fuel and structural element.

\subsection{Functional Properties of Lima Bean Flour}

\subsubsection{Emulsion Capacity}

The emulsion capacity observed at natural $\mathrm{pH}$ (7.0) of lima bean was $4.35 \mathrm{ml} / \mathrm{g}$ sample for lima bean flour. Nwoji (2005) also reported a range of 2.2-10.6ml oil per gram sample for different bean flour. The emulsion capacity of lima bean flour may be attributed to protein in the flour.

\subsubsection{Water and Oil Absorption Capacity}

The lima bean flour recorded a water absorption capacity of $1.95 \mathrm{ml} \mathrm{H}_{2} \mathrm{Og} / \mathrm{g}$. This was respondent to that reported by Prakash and Narasinga (1986) and within the range of commercial values of protein concentrate $(1.90-2.20 \mathrm{ml} / \mathrm{g}$. The result of these analyses shows that lima bean flour is a good water and oil absorption capacity. 
Table 3. Functional Properties of Dehulled and Undehulled Lima Bean Flour

\begin{tabular}{lll}
\hline Functional Properties & Dehulled seeds $(\%)$ & Undehulled seeds $(\%)$ \\
\hline Water absorption $(\mathrm{g} / \mathrm{g})$ & $2.238 \pm 0.138$ & $9.81 * \pm 0.07$ \\
Bulk density $(\mathrm{g} / \mathrm{ml})$ & $0.80 \pm 0.02$ & $0.88 \pm 0.30$ \\
Oil absorption $(\mathrm{g} / \mathrm{g})$ & $1.9908^{*} \pm 0.01$ & $1.212 \pm 0.01$ \\
Emulsion capacity $(\mathrm{g} / \mathrm{ml})$ & $4.35^{*} \pm 0.338$ & $3.03 \pm 0.08$ \\
Foam capacity $(\%)$ & $31.67 * \pm 0.311$ & $25.33 \pm 0.25$ \\
\hline asterisk $(*)$ within a row is significantly different $(\mathrm{P}>0.05)$
\end{tabular}

*... means with asterisk $(*)$ within a row is significantly different $(\mathrm{P}>0.05)$

\subsubsection{Foam Capacity}

The foaming capacity of the dehulled lima bean flour were recorded as $31.67 \%$, this property makes lima bean flour especially the dehulled, exceptionally useful as an aerating agent in food system like moi-moi, akara, e.t.c as well as other product which require the production of a stable foam.

\subsubsection{Bulk Density}

The dehulled flour was observed to have bulk density of $0.82 \mathrm{~g} / \mathrm{ml}$. this is important because the properties of the bulk can influence the processing operation.

\section{Conclusion}

The local lima bean cultivar (okpokoro) was observed to have high fiber content, though the undehulled lima bean flour gave higher result than the dehulled. It can be used as a good source of fiber in less developed and developing countries. From the result the dehulled lima bean had increased functional properties compared to undehulled lima bean which shows that dehulled lima bean can be utilized in preparing local delicacies like 'moi moi' and 'akara'.

\section{Recommendation}

With the high fiber contents of lima bean (okpokoro), the flour can be utilized as a supplement for people with diabetes suffering insulin resistance. Effort should be made to incorporate it in convenient foods as well as a compliment to wheat flour in the preparation of composite product, baked product e.t.c. in addition, improved method for the processing especially dehulling process and utilization should be encouraged for economic growth and to enhanced human consumption.

\section{References}

Abbey, B. W., \& Ibeh, G. O. (1988). Functional Properties of Raw Heat Processed Cowpea (Vigna unguicuata) Flour. J. food Sci., 53, 1775-1777. https://doi.org/10.1111/j.1365-2621.1988.tb07840.x

AOAC (2005). Official Methods of Analysis. AOAC International Washington D.C. 17th Edn. pp. 1456-1500.

Beuchat, L. R., Chery, Y. P., \& Quim, M. R. (2000). Physiochemical Latinomericanos De Nutrition. Caracas Venezuela. pp. 140-149.

Bliss, F. A. (1975). Cowpea in Nigeria. In: Proceeding of a Symposium on Nutritional Improvement of Legumes by Breeding. 3-5 July, 1975, New York, United Nations Protein Advisory Group. pp. 364-456.

Carcea, B. M. (1986). Functional Properties of Drum Dried Chick Pea (Cicer aritinum L.) flour. J. Food Sci., 51, 1518-1526. https://doi.org/10.1111/j.1365-2621.1986.tb13849.x

Chukwu, M. N., Nwakodo, C. S., Ndulaka, J. C., \& Nwokocha, N. J. (2018). Production and Proximate Composition of Ogiri-Ahuekere (Arachis hypogaea Linn) Seed Condiment. Research Journal of Agriculture and Environmental Management, 7(1), 007-017.

Droughty, J., \& Walker, A. (1982). Legumes in Human Nutrition $2^{\text {nd }}$ Edition. Food and Agriculture Organization of the United Nation, Rome. FAO and Nutrition Paper No. 20.

Davidson, S., Passmore, R., Brock, J. F., \& Truswell, A. S. (1975). Human Nutrition and Dietetics (6th Edn). The English Language Book Society and Churchill Livingstone, New York. pp. 110-115

Edeogu, C. O., Ezeonu, F. C., Okaka, A. N. C., Ekuma, C. E., \& Elon, S. O. (2007). Proximate Composition of Staple Food Crops in Ebonyi State, South Eastern Nigeria. International J. Biotech. Biochem, 3(1), 57-68.

Enwere, N. (1985). Effect of Tempering and Drying on Selected Functional Properties and Performance of Legumes Flour during Akara and Moi-Moi Preparation. Msc. Thesis University of Nigeria, Nsuka. 
Fashakin, K. B., \& Fasanya, J. I. (1988). Chemical composition and Nutritive Changes of Some Improved Varieties of Cowpea (Vigna unguiculata). Tropical Sci., 28, 111-118.

Ibeabuchi, J. C. (2014). Proximate and Functional Properties of Raw and Fermented Bottle Gourd Seeds (Lagenaria siceraria). International Journal of Biotechnology and Food Science, 2(4), 82-87.

Ihekoronye, A. I., \& Ngoddy, P. O. (1985). Integrated Food Science and Technology for the Tropics. Macmillian Publ. London. pp. 283-285.

Jenkins, D. J. A., Woleverm, T. M. S., \& Taylor, R. H. (1982). Slow Release Dietary Carbohydrate Improves Second Meal Tolerance. J. American Chemistry Nutrition, 35, 1339-1346. https://doi.org/10.1093/ajcn/35.6.1339

Muhammed, A. K., Jacobson, I., \& Eggunm, B. O. (1979). Nutritive Value of Some Improved Varieties of Legumes. J. food Sci. and Technol., 30, 395-400.

Muller, H. G. (1998). An Introduction to Tropical Food Science. Cambridge University Press, New York. pp. 122-116.

Maia, F. M. M., Ohveriram, J. T. A., Natos, M. R. T., Moreira, R. A., \& Vasconcelas, I. M. (2000). Proximate Composition and Contents and hacagglutimating and Lysine-Inhibiting Activities of Some Brazillim vigna unguiculata Walp cultivars. F. Sci Food Agric., 80, 454-458.

https://doi.org/10.1002/(SICI)1097-0010(200003)80:4<453::AID-JSFA548>3.0.CO;2-X

Naczk, M., Diosady, L. L., \& Rubin, I. J. (1985). Functional Properties of Canola Meals Produced by Two-Phase Solvent Extraction System. J. Food Sci., 50, 1685-1692. https://doi.org/10.1111/j.1365-2621.1985.tb10565.x

Njoku, B. A., \& Banigo, E. O. I. (2006). Physio-chemical Properties of Precooked Cassava (Manihot esculenta Crantz) Flour Prepared by Adaptation of a Traditional Process. Nigerian Food Journal, 24(1), 98-106. https://doi.org/10.4314/nifoj.v24i1.33639

Okaka, J. C. (1997). Cereals and Legumes Storages and Processing Technology. Data and Microsystems Publ, Enugu. pp. 2-13.

Onwuka, G. I. (2005). Food Analysis and Instrumentation. Naphtali Prints, Lagos. pp. 133-137.

Onwuliri, V. A., \& Obu, J. A. (2002). Lipids and Other Constituents of Vigna unguicuata and Phaseolus vulgaris Grown in Northen Nigeria. J. Food Chem., 78, 7-17. https://doi.org/10.1016/S0308-8146(00)00293-4

Prakash, V., \& Narasinga, M. S. (1986). Physiochemical Properties of Oil Seed Proteins. CRC Crit. Rev. Biochem., 20, 265-363. https://doi.org/10.3109/10409238609083736

Ramcharram, C., \& Walker, A. F. (1985). Changes in the Nutritional Value of Starchy Legumes Due to Adverse Storage Condition. J. Plant Food, 6, 73-88. https://doi.org/10.1080/0142968X.1985.11904300

Sosulski, F. W. (1962). The Centrifuge Methods for Determining Flour Absorption in Hard-red Spring Wheat Cereal. Chemical, 39, 344.

Wolf, W. T. (1970). Soybean Protein. Their Functional, Chemical and Physical Properties. J. Agric. Food Chem., 18, 969-975. https://doi.org/10.1021/jf60172a025

\section{Copyrights}

Copyright for this article is retained by the author(s), with first publication rights granted to the journal.

This is an open-access article distributed under the terms and conditions of the Creative Commons Attribution license (http://creativecommons.org/licenses/by/4.0/). 